International Journal of Environment, Agriculture and Biotechnology
Vol-6, Issue-1; Jan-Feb, 2021
Journal Home Page Available: $\underline{\text { https://ijeab.com/ }}$
Journal DOI: $\underline{10.22161 / \text { ijeab }}$

\title{
Isolation and Characterization of Phylloplane Bacteria from Papaya Plant for the Biocontrol of post-harvest Diseases in Papaya
}

\author{
Ashwini Narasimhan*, Kasturi Banerjee
}

Jain University, Bengaluru, India

*Corresponding author

Received: 03 Dec 2020; Received in revised form: 21 Jan 2021; Accepted: 19 Feb 2021; Available online: 28 Feb 2021

(C)2021 The Author(s). Published by Infogain Publication. This is an open access article under the CC BY license

(https://creativecommons.org/licenses/by/4.0/).

\begin{abstract}
Papaya is one of the most significant crops cultivated in tropical and subtropical countries all over the world. Post-harvest diseases are the major threat to papaya fruit yield leading to huge losses. This study focuses on controlling the fungal pathogens of papaya fruit by isolating the disease control bacteria from the phylloplane of the papaya plant and screening them for antagonism towards the pathogens. The fungal pathogens chosen for this study were Colletotrichum, Fusarium and Rhizopus. The three bacterial isolates showing the maximum diameter for the zone of inhibition against these pathogens were selected for morphological and biochemical characterization. In studies, the isolates were found to be Bacillus and Pseudomonas. Consortium study was conducted between Bacillus and Pseudomonas which showed more efficiency in controlling the growth of fungal pathogens when combined. Fruit assay was then performed to establish these bacterial isolates as biocontrol agents. Papaya fruits were inoculated with fungal pathogens and fungal pathogens along with bacterial isolates. It was observed that the papayas inoculated with bacterial isolates showed a better shelf life than those without. The present study reports the biocontrol ability of the bacteria which can be used as disease control agents.
\end{abstract}

Keyword-Biocontrol, papaya, post-harvest diseases, phylloplane, fungal pathogens.

\section{INTRODUCTION}

Papaya, (Carica papaya), also called papaw or pawpaw, is a tropical and sub-tropical fruit that is classified under various plant families, including Passifloraceae, Cucurbitaceae, Bixaceae, and Papayaceae. Currently, it is placed under Caricaceae, a plant family incorporating species in four genera, Carica, Cylicomorpha, Jacaratia and Jarilla [1].

An additional aspect of the mechanisms of the pesticides through which they reduce plant growth is exhibited [2]. Thus, there is a need for new solutions to plant disease problems that provide effective control while minimizing negative consequences for human health and the environment [3]. Biological control, using microorganisms to suppress plant disease has offered a powerful alternative to the use of synthetic chemicals [4].
The production of phytopathogen inhibitor compounds by the biocontrol agents and their biocontrol potential was evaluated by measuring the production of these compounds, hydrolytic enzymes (amylases, lipases, proteases, and chitinases) and phosphate solubilisation [5]. It has been proven that induced resistance as an alternative for the control of postharvest diseases in fruit is effective in both the laboratory and a few cases in the field [6]. Biocontrol of diseases in plants is a difficult subject for understanding because these diseases mostly occur in the non-static environment such as the interface of the plant root and the aerial parts of plants [7].

\section{REVIEW OF LITERATURE}

Papaya is majorly cultivated in the region of tropics and sub-tropics. According to a report in 2004, this fruit was 
produced over 6.8 million tonnes (Mt) worldwide, which is about 389,990 Ha [8]. Fungal plant pathogens are known to cause considerable post-harvest loss of fruit and vegetables [9]. Papaya is susceptible to more than a dozen fungal pathogens like Phytophthora rot (Phytophthora palmivora) root and fruit rot, anthracnose (Collectricum gloerosporioides), powdery mildew (Oidium caricae), Rhizopus rot (Rhizopus stolonifer) and black spot (Asperisporium caricae) are, however, the more important fungal pathogens [10]. Anthracnose, caused by Colletotrichum gloeosporioides (Penz.), primarily affects papaya fruit and is an important postharvest disease in most tropical and subtropical regions [11].

The widespread use of pesticides in agricultural settings, public health, commerce, and individual households throughout the world is an indication of the importance of these compounds [12]. The sources of these chemicals are houses, factories, water bodies etc which finds their applications in public spaces; home, garden, and lawn use and occupational association [13]. Due to the interest in public safety concerns, the exploitation of the integrated pest management aspect in being worked on [14].

Biocontrol microbes/micro-organisms are cellular or noncellular entities, capable of replication or of transferring genetic material. The list of biocontrol agents included in CIB for registration is many [15]. The dual activity of Pseudomonas BCAs (i.e. direct antagonism of phytopathogens and induction of disease resistance in the host plant) further highlights their potential as plant protection products (PPPs) [16]. In current times, the focus is aimed at understanding, how Pseudomonas strains to act as efficient biological control agents. This approach of understanding the mechanism is helping the development of novel strains with enhanced modified traits for its increased biocontrol efficacy [17].

Elicitors, as a part of integrated pest management (IPM) approach, are usually used to induce resistance against postharvest diseases [18]. It has been proven that induced resistance as an alternative for the control of postharvest diseases in fruit is effective in both the laboratory and a few cases in the field [6]. The results of various studies confirmed the potential use of some essential oils for protection of fruits and vegetables against postharvest pathogens and for increasing the shelf life of plant products [19].

\section{MATERIALS \& METHODS}

\subsection{Isolation and screening of bacteria}

Potent bacterial biocontrol agents were obtained from phylloplane of papaya.
5 different phylloplane samples were procured from the papaya growing fields in Bangalore.

Isolation of phylloplane bacteria was carried out by the leaf imprint method [20]. These plates were then incubated at $37^{\circ} \mathrm{C}$. The isolates obtained were maintained on nutrient agar plates.

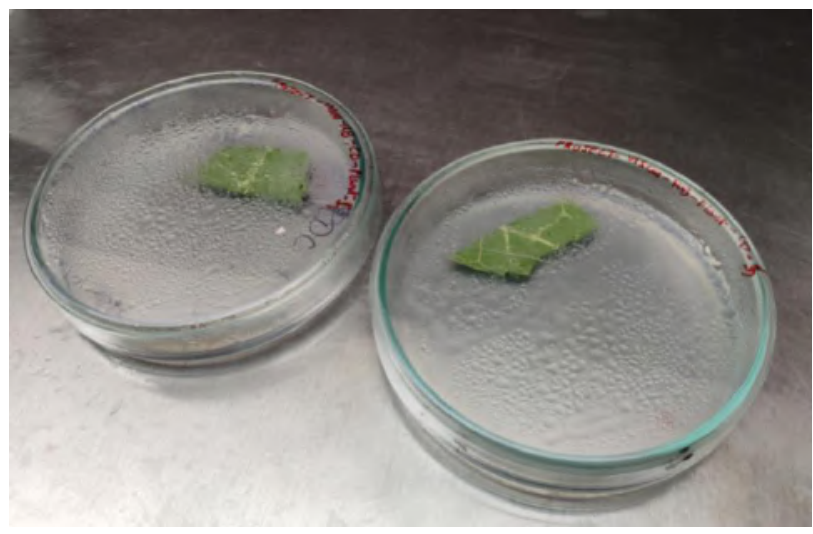

Fig. I. Leaf Imprint method

\subsection{Procurement of potent papaya fungal pathogens}

Fungal pathogens were isolated from diseased papaya fruits which were collected from vegetable and fruit markets. The pathogens were isolated by direct plating on Potato Dextrose Agar. The plates were incubated at room temperature.

The following are the pathogens that were isolated from the diseased papaya.
1) Colletotrichum $\mathrm{sp}$.
2) Fusarium (type 1)
3) Fusarium (type 2)
4) Rhizopus
5) Penicillium

\subsection{Dual assay of phylloplane bacteria against papaya fungal pathogens}

To test the antagonistic potential of each isolate, the pathogen and bacteria were inoculated $3 \mathrm{~cm}$ apart on potato dextrose agar plates. Fungal growth on each plate was observed and the zone of inhibition, if present, was determined. The treatments were replicated in triplicates for statistical validation. Results were expressed in terms of percentage inhibition which was calculated as per the given formula.

$$
\% \text { inhibition }=\frac{\text { Diameteroftheinhibitionzone }}{\text { Totaldiameter }} \times 100
$$

\subsection{Morphological characterization of the isolates}

Morphological characteristics like cell and spore morphology, motility; growth characteristics (growth in the presence of $\mathrm{NaCl} 7 \%$ ) were investigated [21]. Gram staining was performed by standard procedures.

\subsection{Biochemical characterization of the isolates}


Various biochemical tests were conducted based on Table I. Various treatments with its abbreviations

Bergey's manual of systematic bacteriology and Manual of Microbiology Methods [22].

3.6. Evaluation of Individual and Consortium biocontrol potential

The individual biocontrol agents, as well as the consortiur of biocontrol agents, were co-inoculated into tubes containing potato dextrose broth to evaluate and compare the potential of biocontrol capacity. This was conducted between the obtained isolates. The tubes were then kept for incubation at room temperature for a week. At the end of the incubation period, dry weight analysis was performed by filtering out the fungi on a filter paper and subjecting $t$ to hot air oven mediated drying at $60^{\circ} \mathrm{C}$ for 1 hour [23]. The dry weight of the fungi was taken and inhibition \% was calculated.

\subsection{Preliminary bioassay to evaluate disease control ability of the isolates}

\section{INVITRO BIOASSAY}

Disease control potential of the isolates was checked on papaya fruits in vitro. Fruits were spot inoculated [24] and subjected to various treatments. The treatments were replicated in triplicates for statistical validation.

\begin{tabular}{|c|c|}
\hline ABBREVIATION & TREATMENT \\
\hline T1 & CONTROL \\
\hline $\mathrm{T} 2$ & RHIZOPUS \\
\hline T3 & IS-6 + RHIZOPUS \\
\hline $\mathrm{T} 4$ & IS-7 + RHIZOPUS \\
\hline T5 & COLLETOTRICHUM \\
\hline T6 & IS-6 + COLLETOTRICHUM \\
\hline $\mathrm{T} 7$ & IS-7 + COLLETOTRICHUM \\
\hline $\mathrm{T} 8$ & FUSARIUM \\
\hline T9 & IS-6 + FUSARIUM \\
\hline T10 & IS-7 + FUSARIUM \\
\hline
\end{tabular}

\section{RESULT \& DISCUSSION}

\subsection{Dual Plate Assay}

The bacterial isolates obtained from the phylloplane samples were subjected to screening using a dual plate assay method. 3 different isolates numbered IS1, IS6 and IS7 exhibited a good percentage of inhibition against the fungal pathogens and hence were chosen for further studies.

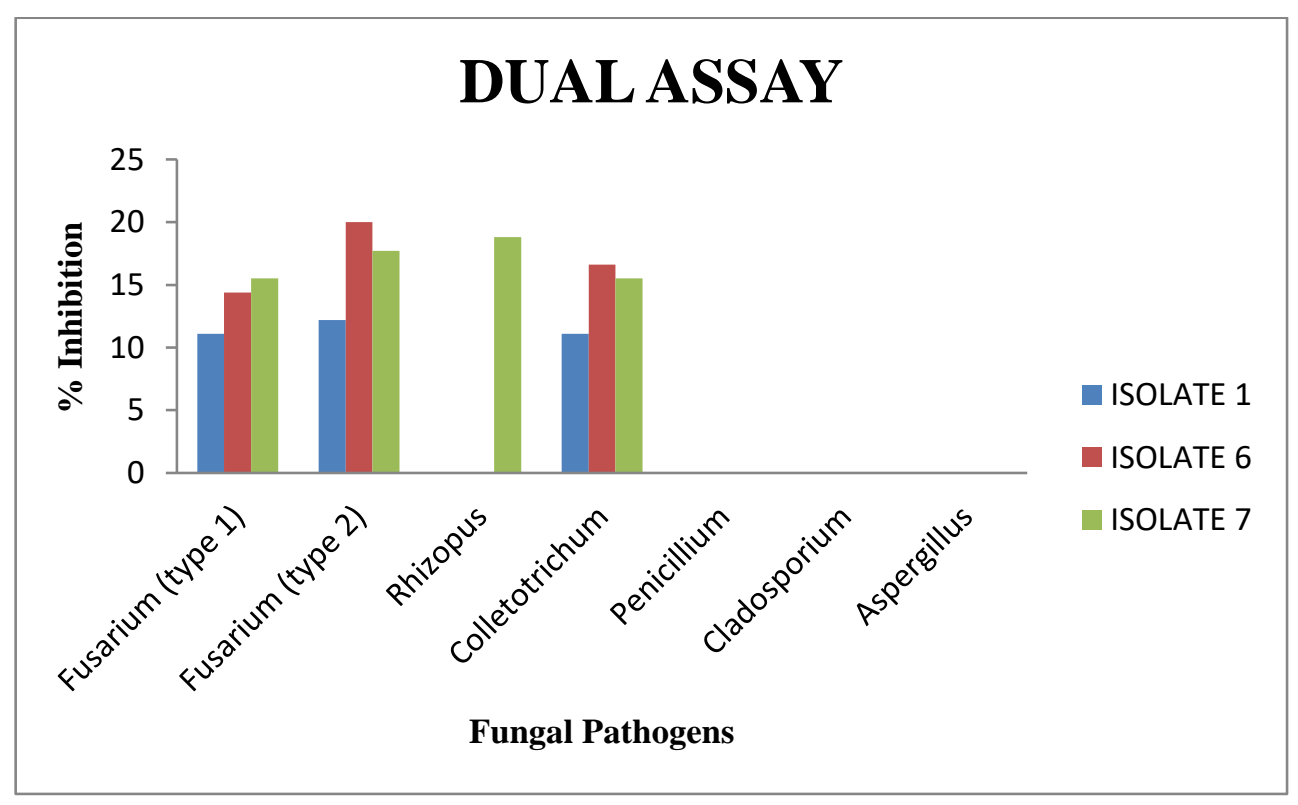

Fig. II. Dual assay of phylloplane bacteria against papaya fungal pathogens

\subsection{Morphological and Biochemical characterization}

Isolate 1 was found to be gram-positive rods; Isolate 6 was identified as gram-positive, spore-forming rods. The hanging drop method confirmed it to be motile rods. It was able to degrade starch and casein. It showed positive for catalase test, negative for citrate and gelatin liquefaction. It was able to grow well on a nutrient agar plate containing $7 \% \mathrm{NaCl}$. Isolate 7 was identified based on its colony colour on nutrient agar, its gram character, its inability to ferment sugars tested, MR, VP, catalase, oxidase, citrate and gelatin liquefaction tests.

Thus, IS6 was identified as Bacillus and IS7 was identified as Pseudomonas.

\subsection{Evaluation of Individual and Consortium biocontrol potential}


The consortia of IS6 and IS7 showed higher disease control potential in papaya fruit against the pathogens
Fusarium (type 2) and Colletotrichum.

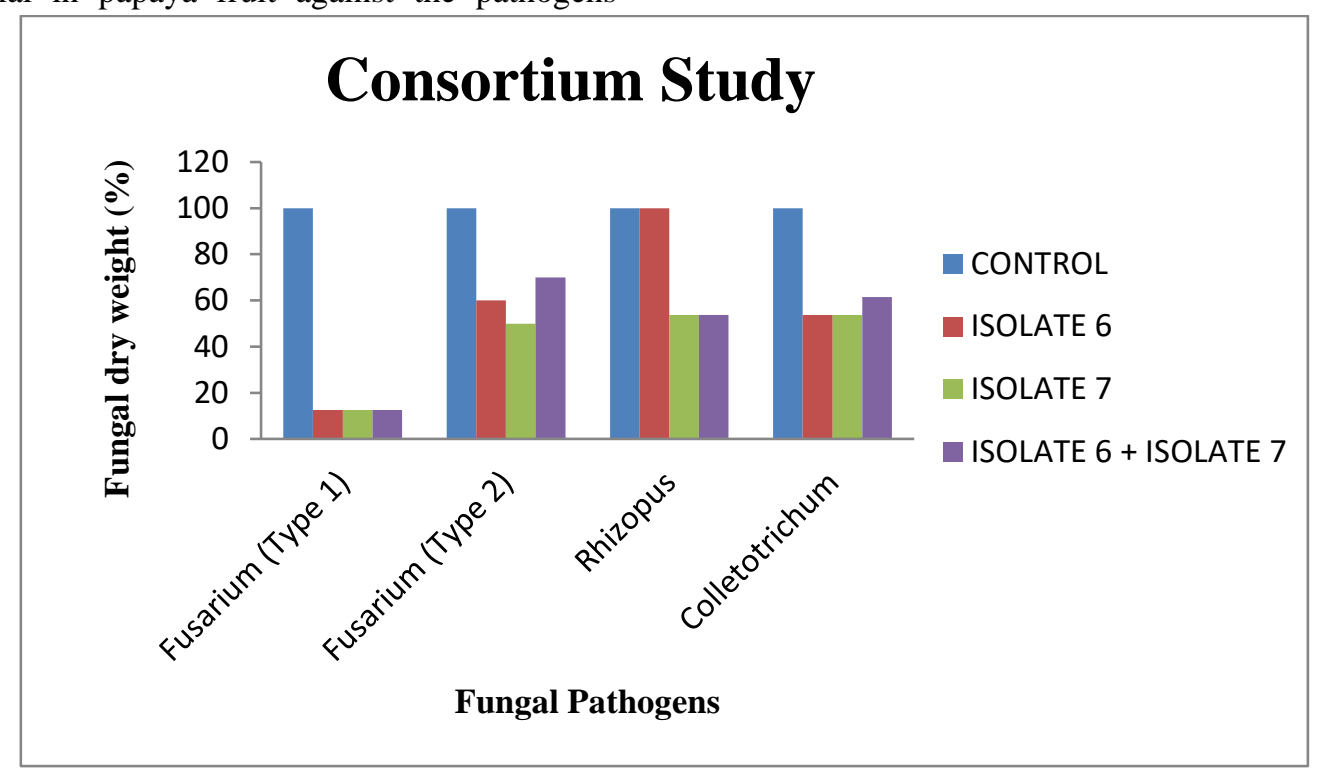

Fig. III. Evaluation of Individual and Consortium biocontrol potential

\subsection{Invitro bioassay to determine the disease control potential of the isolates}

Fruit assay conducted to assess the shelf life of the papaya fruits and disease control potential of the isolates under in vitro conditions showed that fruits treated with the isolates and the pathogen exhibited better shelf life and appeared fresh in comparison with the control and only pathogen inoculated fruit. The reason for the same could be bacterial-fungal antagonism where the disease control bacterial isolates might produce antifungal metabolites or modify the environment such that the fungal pathogens are unable to grow. Fruits co-inoculated with IS -7 and the pathogens showed the maximum freshness. This shows the significant biocontrol ability of post-harvest diseases of the phylloplane bacterial isolates.
Table II. Invitro bioassay to determine the disease control potential of the isolates

\begin{tabular}{|c|c|}
\hline TREATMENTS & $\begin{array}{c}\text { INFECTION } \\
\text { PERCENTAGE (\%) }\end{array}$ \\
\hline T1 & $22.2 \pm 1.0$ \\
\hline T2 & $100 \pm 1.2$ \\
\hline T3 & $100 \pm 1.2$ \\
\hline T4 & $11.1 \pm 0.7$ \\
\hline T5 & $100 \pm 1.2$ \\
\hline T6 & 0 \\
\hline T7 & 0 \\
\hline T8 & $100 \pm 1.2$ \\
\hline T9 & $11.1 \pm 0.7$ \\
\hline T10 & 0 \\
\hline
\end{tabular}




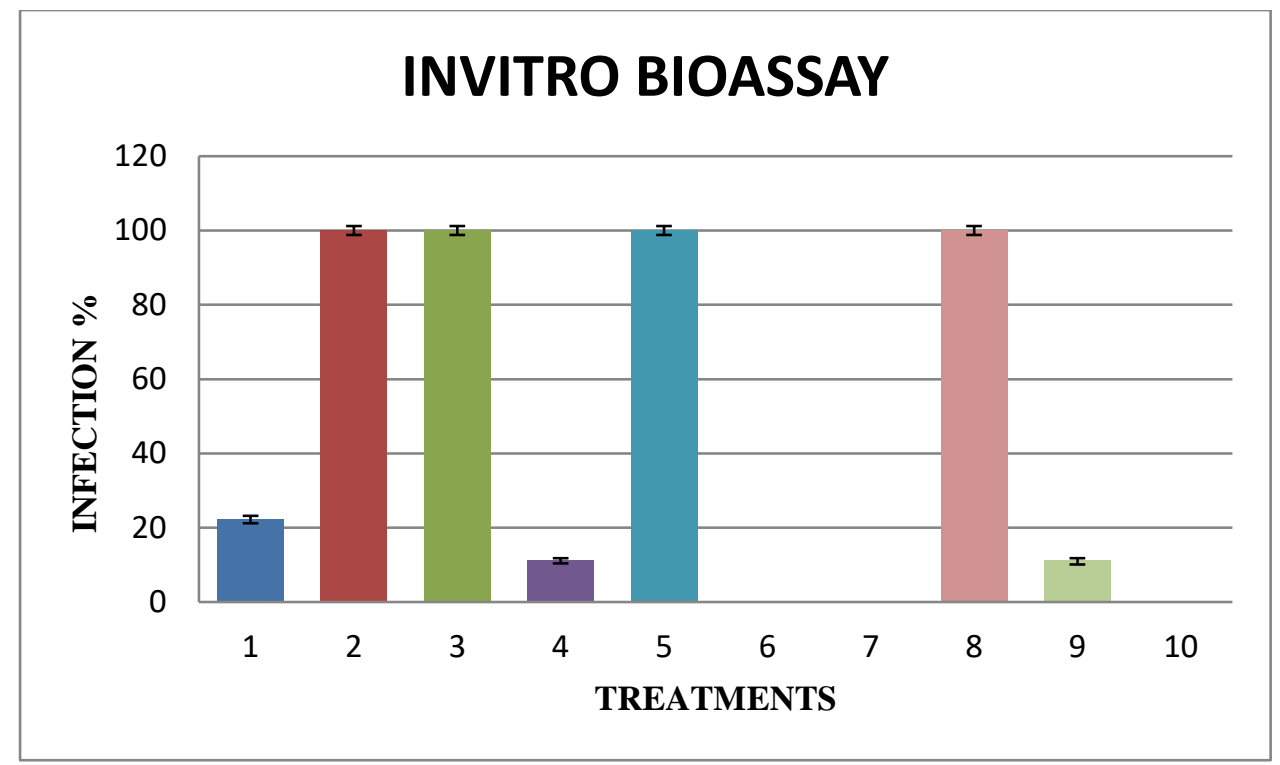

Fig. IV. Invitro bioassay to determine the disease control potential of the isolates

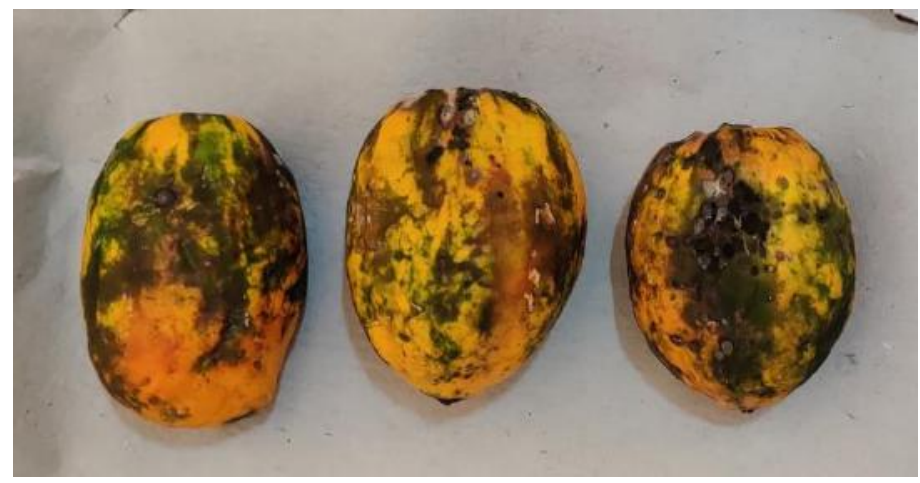

Fig. V. Control (papaya fruits without any treatment)

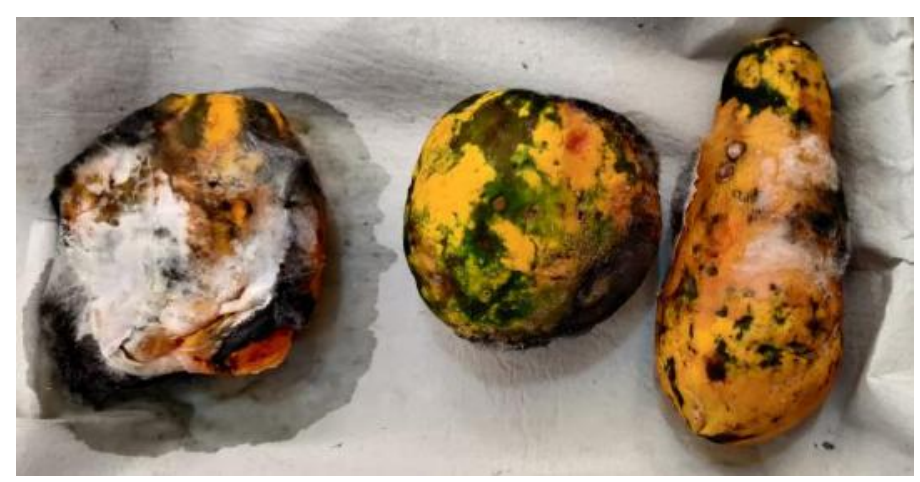

Fig. VI. Papaya fruits inoculated with Rhizopus 


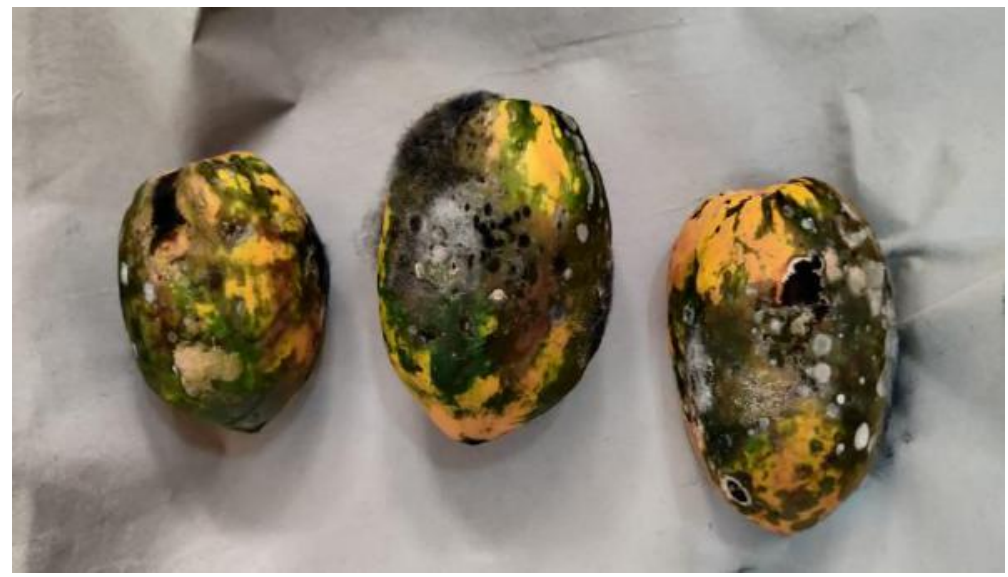

Fig. VII. Papaya fruits inoculated with Rhizopus and Isolate 6

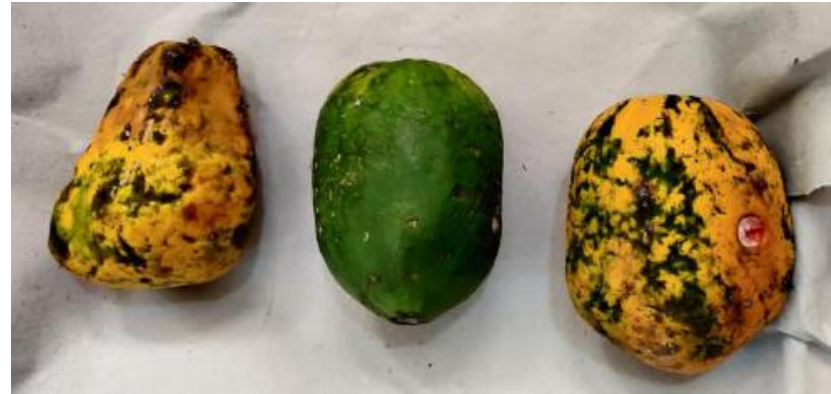

Fig. VIII. Papaya fruits inoculated with Rhizopus and Isolate 7

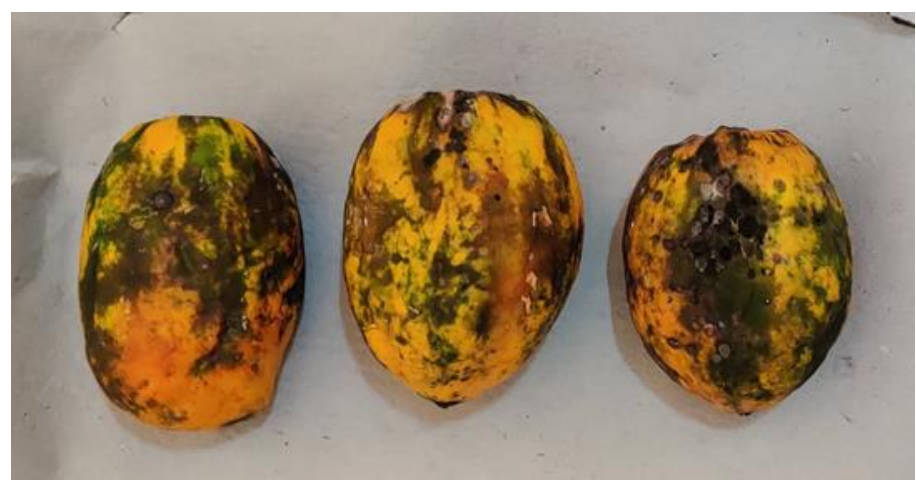

Fig. IX. Control (papaya fruits with any treatment)

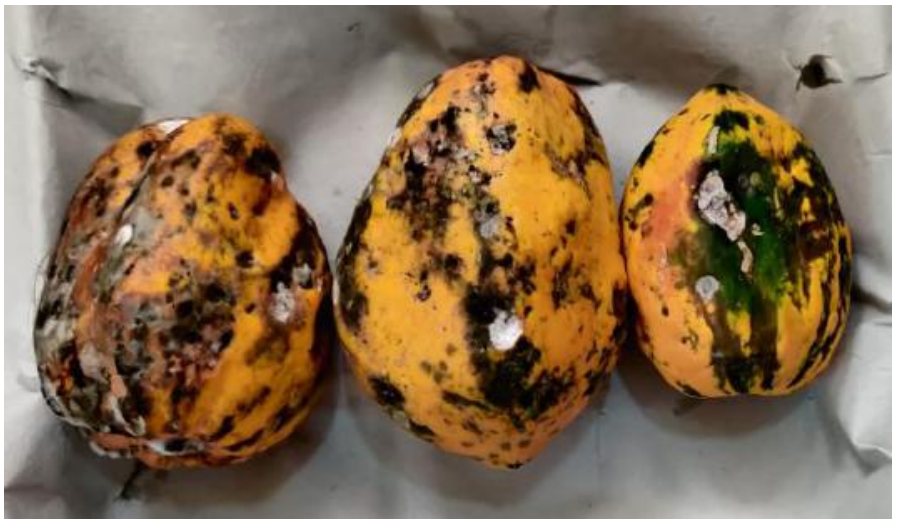

Fig. X. Papaya fruits inoculated with Colletotrichum 


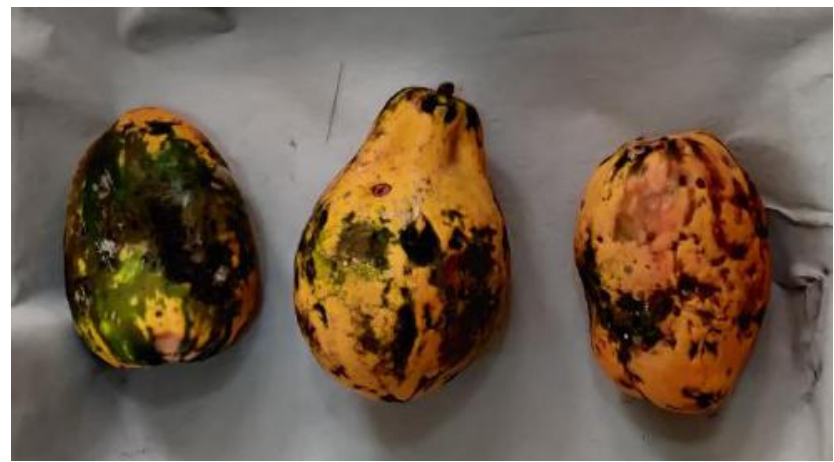

Fig. XI. Papaya fruits inoculated with Colletotrichum and Isolate 6

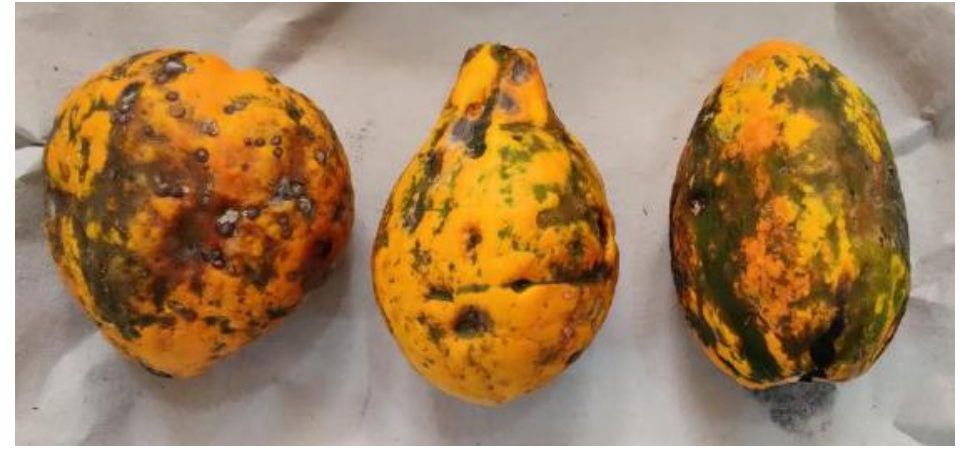

Fig. XII. Papayas fruits inoculated with Colletotrichum and Isolate 7

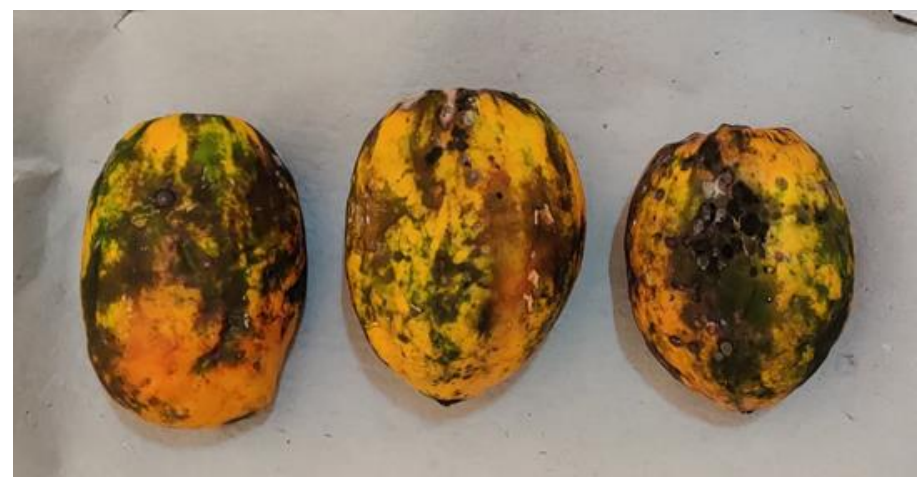

Fig. XIII. Control (papaya fruits with any treatment)

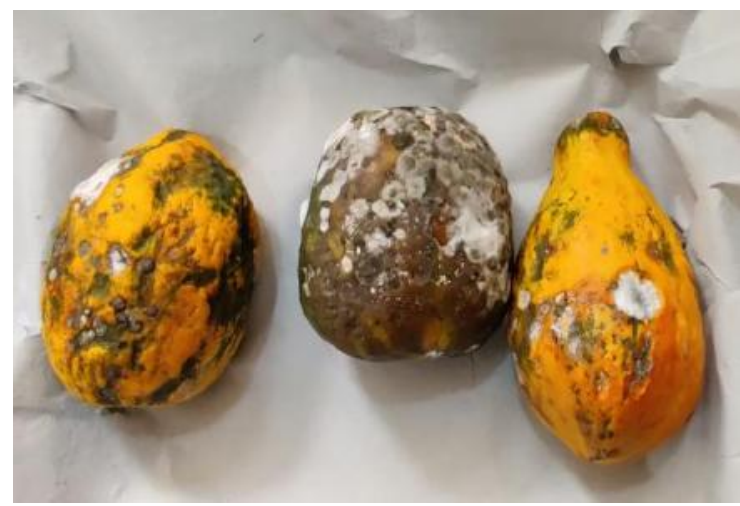

Fig. XIV. Papaya fruits inoculated with Fusarium 


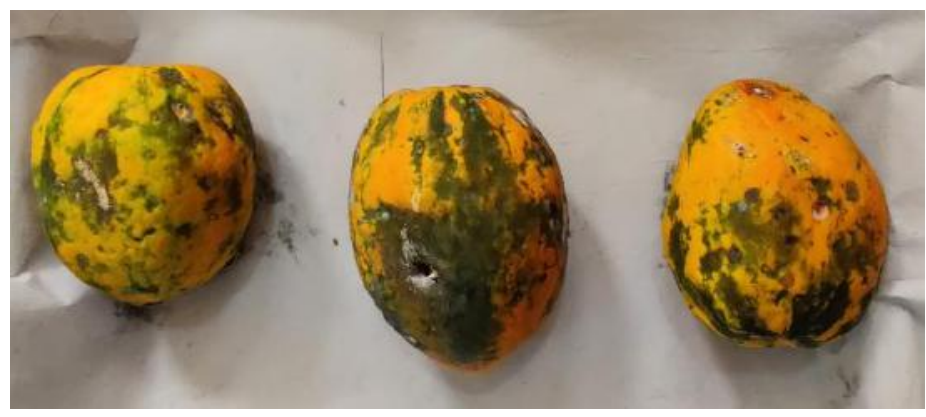

Fig. XV. Papaya fruits inoculated with Fusarium and Isolate 6

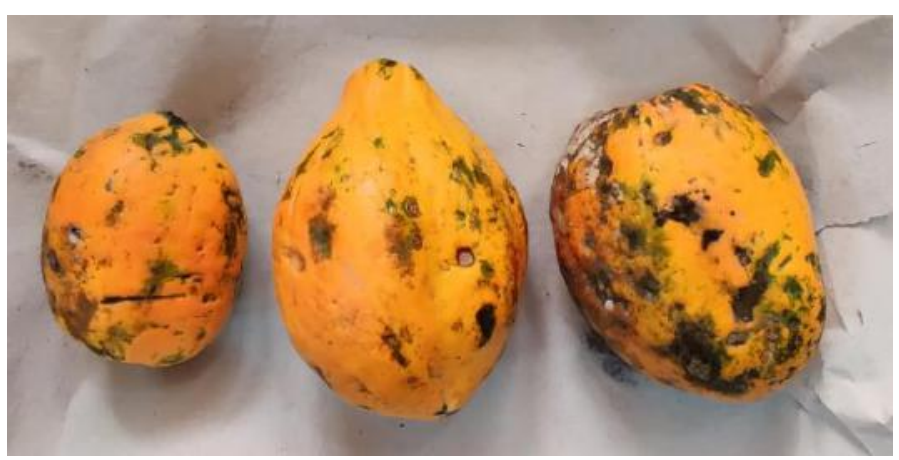

Fig. XVII. Papaya fruits inoculated with Fusarium and Isolate 7

\section{CONCLUSION}

From the studies conducted it is observed that bacterial isolates from the phylloplane have the ability to control fungal pathogen growth in papaya fruits. Out of 20 isolates studied, it can be concluded that IS 6 and IS 7 had maximum inhibitory activity and increased shelf life of the papaya fruits. These two isolates were found to be Grampositive rods with endospores and Gram-negative rods, respectively. The maximum inhibition was seen against Fusarium. By the Dual assay test, it was revealed that maximum antagonistic ability was revealed by IS -6 and IS -7 . The papaya fruits treated with IS -6 and are -7 showed better shelf life and appeared fresh. The isolates were morphologically and biochemically characterized and identified as Bacillus and Pseudomonas respectively. Thus it can be concluded that Bacillus and Pseudomonas obtained from the phylloplane of the papaya plant act as potential biocontrol agents against various post-harvest diseases of papaya.

\section{FUTURE SCOPE}

- Pathogenicity testing of the potential biocontrol agents

- Mode of action of the biocontrol agents

- Formulation studies

- Field studies
- Extension of post-harvest biocontrol potential to other fruits and vegetables

\section{ACKNOWLEDGEMENT}

This project consumed a huge amount of work, research and dedication, which would not have been possible without the support of my parents, teachers and friends. Also, many thanks to the management of Jain University for providing this opportunity and infrastructural support.

\section{REFERENCES}

[1] Kumar, L. S. S., \& Srinivasan, V. K. (1944). CHROMOSOME NUMBER OF CARICA DODECAPHYLLA VELL FL. FLUM. Current Science, 13(1), 15-15.

[2] Ahemad, M., \& Khan, M. (2011). Toxicological assessment of selective pesticides towards plant growthpromoting activities of phosphate solubilizing Pseudomonas aeruginosa. Acta microbiologica et immunologica Hungarica, 58(3), 169-187.

[3] Cook, R. J. (1993). Making greater use of introduced microorganisms for biological control of plant pathogens. Annual review of phytopathology, 31(1), 53-80.

[4] Bennett, M. A. (1998). The use of biologicals to enhance vegetable seed quality. Seed Technology, 198-208.

[5] Feofilova, E. P. (2010). The fungal cell wall: modern concepts of its composition and biological function. Microbiology, 79(6), 711-720. 
[6] Tian, S. P., \& Chan, Z. L. (2004). Potential of induced resistance in postharvest diseases control of fruits and vegetables. Acta Phytopathology Sinica, 34(5), 385-394.

[7] Bailey, J. S., Cushnahan, A., \& Beattie, J. A. M. (1997). The diagnosis and recommendation integrated system (DRIS) for diagnosing the nutrient status of grassland swards: II. Model calibration and validation. Plant and Soil, 197(1), 137-147.

[8] Machethe, C. L. (2004, October). Agriculture and poverty in South Africa: Can agriculture reduce poverty. In Paper presented at the Overcoming Underdevelopment Conference held in Pretoria (Vol. 28, p. 29).

[9] Tripathi, P., \& Dubey, N. K. (2004). Exploitation of natural products as an alternative strategy to control postharvest fungal rotting of fruit and vegetables. Postharvest biology and Technology, 32(3), 235-245.

[10] Zhu, Y. J., Agbayani, R., \& Moore, P. H. (2004). Green fluorescent protein as a visual selection marker for papaya (Carica papaya L.) transformation. Plant Cell Reports, 22(9), 660-667.

[11] Lakshmi, B. K. M., Reddy, P. N., \& Prasad, R. D. (2011). Cross-infection potential of Colletotrichum gloeosporioides Penz. isolates causing anthracnose in subtropical fruit crops.

[12] Dwivedi, N., Bhutia, Y. D., Kumar, V., Yadav, P., Kushwaha, P., Swarnkar, H., \& Flora, S. J. S. (2010). Effects of combined exposure to dichlorvos and monocrotophos on blood and brain biochemical variables in rats. Human \& experimental toxicology, 29(2), 121-129.

[13] Fenner-Crisp, P. A. (2010). Risk assessment and risk management: the regulatory process. In Hayes' Handbook of Pesticide Toxicology (pp. 1371-1380). Academic Press.

[14] Reuveni, R. (1995). Novel approaches to integrated pest management (No. 632.9 N448). Lewis Publishers.

[15] Rizvi, P. Q., Choudhury, R. A., \& Ali, A. (2009). Recent advances in biopesticides. In Microbial Strategies for Crop Improvement (pp. 185-203). Springer, Berlin, Heidelberg.

[16] Pieterse, C. M., \& Van Loon, L. C. (1999). Salicylic acidindependent plant defence pathways. Trends in plant science, 4(2), 52-58

[17] Walsh, U. F., Morrissey, J. P., \& O'Gara, F. (2001). Pseudomonas for biocontrol of phytopathogens: from functional genomics to commercial exploitation. Current Opinion in Biotechnology, 12(3), 289-295.

[18] Terry, L. A., \& Joyce, D. C. (2004). Elicitors of induced disease resistance in postharvest horticultural crops: a brief review. Postharvest Biology and Technology, 32(1), 1-13.

[19] Feng, W., \& Zheng, X. (2007). Essential oils to control Alternaria alternata in vitro and in vivo. Food control, 18(9), 1126-1130.

[20] Yadav, R. K. P., Kakamanoli, K., \& Vokou, D. (2010). Estimating bacterial population on the phyllosphere by serial dilution plating and leaf imprint methods. Ecoprint: An International Journal of Ecology, 17, 47-52.

[21] Balkwill, D. L. (1989). Numbers, diversity, and morphological characteristics of aerobic, chemoheterotrophic bacteria in deep subsurface sediments from a site in South Carolina. Geomicrobiology Journal, 7(1-2), 33-52.

[22] Young, C. C. (1926). Bergey's manual of determinative bacteriology.

[23] Chee, S. N., Johansen, A. L., Gu, L., Karlsen, J., \& Heng, P. W. S. (2005). Microwave drying of granules containing a moisture-sensitive drug: a promising alternative to fluid bed and hot air oven drying. Chemical and pharmaceutical bulletin, 53(7), 770-775.

[24] Prusky, D., Ben-Arie, R., \& Guelfat-Reich, S. (1981). Etiology and histology of Alternaria rot of persimmon fruits. Phytopathology, 71(11), 1124-1128. 